\title{
PERAN LURAH DALAM MENDORONG PEMBANGUNAN DI KECAMATAN UJUNG TANAH KOTA MAKASSAR
}

\author{
The Role of Urban Village Heads in Promoting Development in Ujung Tanah Sub-district Makassar \\ City
}

\author{
Hamdani Nur ${ }^{1}$, Imran Ismail ${ }^{2}$, Udin B. Sore ${ }^{2}$ \\ ${ }^{1}$ Magister Ilmu Administrasi Negara, Program Pascasarjana, Universitas Bosowa \\ ${ }^{2}$ Program Studi Ilmu Administrasi Negara, Program Pascasarjana, Universitas Bosowa
}

Email: hamdaninur1971@gmail.com

Diterima: 20 Agustus 2020

Dipublikasikan: 07 Desember 2020

\begin{abstract}
ABSTRAK
Penelitian ini menggunakan pendekatan deskriptif kualitatif terhadap kondisi yang terjadi. Metode penelitian dengan deskriptif kualitatif dipilih karena dianggap sesuai dengan tujuan penelitian dengan maksud menggambarkan dan menginterprestasikan masalah yang berkaitan dengan peran lurah dalam mendorong pembangunan di kecamatanUjung Tanah. Data diperoleh dengan menggunakan teknik pengumpulan data dengan cara observasi, wawancara, studi kepustakaan, penelusuran data online, dan dokumentasi. Teknik analisis data pada penelitian ini dilakukan secara cermat sesuai dengan metode penelitian ilmiah berdasarkan konsep analisis data yang digunakan pada metode penelitian kualitatif. Tujuan Dari penelitian ini adalah untuk mengetahui: 1) Seperti apa peran yang dilakukan oleh lurah di kecamatan Ujung Tanah dalam mendorong pembangunan; 2) Untuk mengetahu faktor yang mempengaruhi lurah dalam mendorong pembangunan yang ada di kecamatan Ujung Tanah. Hasil peneliti menunjukkan bahwa: 1) Peran lurah dalam mendorong pembangunan yang ada di kecamatan Ujung Tanah dilakukan melalui peran aktif dan peran partisipatif. Pada kelurahan Tabaringan peran yang dilakukan oleh lurah dalam mendorong pembangunan diwilayahnya dilakukan dengan konsep pendekatan secara persuasive kepada masyarakat sekaligus memberdayakan secara proaktif seluruh masyarakat yang ada wilayah tersebut. Sementara kelurahan Pattingalloang, peran yang dilakukan oleh lurah dalam hal mendorong pembangunan diwilayahnya adalah pendekatan dengan berbasis ketokohan. Dimana pendekatan tersebut melalui lembaga-lembaga yang sengaja dibentuk dan juga melalui peran tokoh-tokoh agama seperti imam mesjid. Sedangkan peran lurah yang dilakukan oleh kepala kelurahan Gusung dalam mendorong pembangunan diwilayahnya dilakukan melalui pendekatan struktur organisasi yang dibuat oleh pemerintah itu sendiri, yang kemudian bekerja sesuai dengan tupoksi dan perannya secara struktur di kelurahan. 2) Faktor-faktor penghambat dalam upaya mendorong pembangunan di kecamatan Ujung Tanah yang dilakukan oleh ketiga lurah dipengaruhi oleh faktor internal dan faktor eksternal. Persoalan kesadaran masyarakat pada dasarnya semuanya sama, dimana masyarakat secara antusias dalam mendukung pembangunan yang ada. Sementara faktor eksternal untuk pemberdayaan masyarakat lurah Tabaringan berbasis partisipatif, sementara lurah Pattingalloang berbasis ketokohan dan lurah Gusung berbasis struktural.
\end{abstract}

Kata Kunci: Partisipasi Masyarakat, Lurah, Pembangunan, Ujung Tanah, Makassar

\begin{abstract}
This study uses a qualitative descriptive approach to the conditions that occur. The research method is descriptive qualitative because it is in accordance with the research objectives by describing and interpreting problems related to the role of urban village heads in encouraging development in Ujung Tanah sub-district. Data obtained by using data analysis techniques by means of observation, interviews, literature study, online data search, and documentation. The data analysis technique in this study was carried out carefully with scientific research methods based on the concept of data analysis used in qualitative research methods. The purpose of this research is to see: 1) What kind of role is played by urban village heads in Ujung Tanah sub-district in encouraging development; 2) To find out the factors that influence the urban village heads in encouraging development in Ujung Tanah sub-district. The results showed that: 1) The role of the urban village head in encouraging development in the Ujung Tanah sub-district was carried out through active and participatory roles. In the Tabaringan village, the role played by the urban village head in the development of the area is carried out with the concept of a persuasive approach to the community at the same time proactively for the entire community in the area. Meanwhile, in the Pattingalloang village, the role played by the urban village head in encouraging development in the area is a character-based approach. The approach is done through deliberately formed institutions and also through religious figures such as mosque imams. Meanwhile, the role of the urban village head which is carried out by the head of the Gusung village in encouraging development in the area is carried out through the organizational structure approach made by the government itself, which then works in accordance with the main tasks and functions of the village structure. 2) Inhibiting factors in the effort to encourage development in the Ujung Tanah subdistrict carried out by the three urban village heads are from internal factors and external factors. The issue of public awareness is in fact all the same, where the community is enthusiastic about supporting the existing development. Meanwhile, the external factor for community empowerment is the participatory-based in Tabaringan, while the Pattingalloang village head is figure-based and the Gusung village head is based on structure.
\end{abstract}

Keywords: Society participation, Village Head, Develompmnet,Sangkarang,Makassar 


\section{PENDAHULUAN}

Hakekatnya tujuan pembangunan suatu bangsa adalah untuk meningkatkan kualitas hidup manusia secara terencana, gradual, bertahap, komprehensif, holistik, sistemik, bertanggung jawab dan berkelanjutan dengan melibatkan peran serta seluruh elemen warga bangsa. dimaksud. Sinergitas yang tinggi antara pemerintah sektor privat dan masyarakat menjadi faktor kunci keberhasilan pencapaian tujuan pembangunan suatu bangsa. Seperti halnya tujuan pembangunan yang tercantum dalam pembukaan UUD 1945.

Keikutsertaan masyarakat dalam pembangunan adalah kesadaran yang tidak bisa muncul dengan sendirinya. Kesadaran tersebut harus dibimbing dan diarahkan sampai mereka bisa mencapai kemandiriannya sendiri. Dengan adanya keterlibatan secara mental dan emosional mulai dari keterlibatan perumusan kebijakan, pelaksanaan, tanggung jawab sampai pemanfaatan pembangunan akan bisa dirasakan secara merata oleh masyarakat dan tidak hanya diserap oleh pihak-pihak tertentu. Pemberdayaan masyarakat ditingkat Kecamatan adalah peningkatan kemampuan dan kemandirian masyarakat dalam meningkatkan taraf hidupnya. Pemberdayaan sendiri merupakan suatu proses yang berjalan terus menerus yang menggerakkan partisipasi Masyarakat.

Dalam memberdayakan masyarakat, selain dilakukan reorientasi peran pemerintah pusat, juga secara sistematis dan konsisten melakukan penyadaran terhadap masyarakat melalui isu-isu lokal yang sesuai dengan kebutuhan dan kepentingan mereka. Upaya yang dilakukan lebih bersifat partisipatoris sehingga mampu menumbuhkan kemampuan masyarakat lokal. Strategi lain adalah melakukan tekanan secara politik terhadap institusi-institusi lokal seperti eksekutif, legislatif, dan yudikatif kehususnya yang menyangkut fungsional kinerja mereka. Tekanan ini dimaksudkan untuk mendorong perbaikan-perbaikan pada kinerja institusiinstitusi formal tersebut agar mampu merespons, merencanakan serta melaksanakan aspirasi-aspirasi yang berkembang di kalangan masyarakat. Dalam pandangan Soekanto (2009) peran yaitu suatu pekerjaan yang dilakukan dengan dinamis sesuai dengan status atau juga kedudukan yang disandang. Status serta kedudukan tersebut sesuai dengan keteraturan sosial, bahkan dalam keteruran tindakan semuanya itu disesuaikan dengan peran yang berbeda. Berbeda dengan Riyadi (2002) dimana peran adalah sebuah orientasi atau konsep yang terbentuk disebabkan karena suatu pihak dalam oposisi sosial di kehidupan masyarakat. Hal tersebut di dasari pada invidu dan juga alasan untuk melangsungkan tindakan yang diinginkan.

Menurut Mifta Thoha (2002) peran yaitu serangkaian perilaku seseorang yang dilakukan dengan berdasarkan dengan karakternya. Kondisi tersebut bisa dilatarbelakangi oleh psikologi seseorang dalam melakukan tindakan yang diinginakan, sesuai dengan kata hatinya. Sementara itu menurut Katz dan Kahn, pengertian peran adalah suatu tindakan yang dilakukan oleh seseorang dengan berdasarkan karakter dan kedudukannya. Hal tersebut di dasari pada fungsi-fungsi yang dilakukan dalam menunjukan kedudukan dan juga karakter kepribadian tiap-tiap manusia yang menjalankannya.

Masyarakat merupakan salah satu sistem sosial, atau kesatuan hidup manusia. Istilah inggrisnya adalah society, sedangkan masyarakat itu sendiri berasal dari bahasa Arab Syakara yang berarti ikut serta atau partisipasi, kata Arab masyarakat berarti saling bergaul yang istilah ilmiahnya berinteraksi.

Menurut Selo Sumarjan (1974) masyarakat adalah orang-orang yang hidup bersama yang menghasilkan kebudayaan. Sementara itu menurut Koentjaraningrat (1994) masyarakat adalah kesatuan hidup manusia yang berinteraksi menurut suatu sistem adat istiadat tertentu yang bersifat kontinyu dan terikat oleh suatu rasa identitas yang sama. Menurut Ralph Linton (1968) masyarakat adalah setiap kelompok manusia yang hidup dan bekerja sama dalam waktu yang relatif lama dan mampu membuat keteraturan dalam kehidupan bersama dan mereka menganggap sebagai satu kesatuan sosial. Menurut Paul B. Horton \& C. Hunt (1993) masyarakat merupakan kumpulan manusia yang relatif mandiri, hidup bersamasama dalam waktu yang cukup lama, tinggal di suatu wilayah tertentu, mempunyai kebudayaan sama serta melakukan sebagian besar kegiatan di dalam kelompok / kumpulan manusia tersebut.

Partisipasi masyarakat dalam pembangunan ditingkat Kecamatan mutlak diperlukan, Karena tanpa adanya partisipasi masyarakat maka pembangunan hanyalah menjadikan masyarakat sebagai objek semata. Salah satu kritik adalah masyarakat merasa "tidak memiliki" dan "acuh tak acuh" terhadap program pembangunan yang ada. Penempatan masyarakat sebagai subjek pembangunan mutlak diperlukan sehingga masyarakat akan dapat berperan serta secara aktif mulai dari perencanaan, pelaksanaan hingga monitoring dan evaluasi pembangunan. Terlebih apabila kita akan melakukan pendekatan pembangunan dengan semangat lokalitas. Masyarakat lokal menjadi bagian yang paling memahami keadaan daerahnya tentu akan mampu memberikan masukan yang sangat berharga. Masyarakat lokal dengan pengetahuan serta pengalamannya menjadi modal yang sangat besar dalam melaksanakan pembangunan.

Keberhasilan pelaksanaan pembangunan ditingkat Kecamatan sangat bergantung kepada peranan pemerintahan Kecamatan dan masyarakatnya. Keduanya harus mampu menciptakan sinergi. Karena Tanpa melibatkan masyarakat, pemerintahan Kecamatan tidak akan dapat mencapai hasil pembangunan secara optimal. Pembangunan hanya akan melahirkan produk-produk baru yang kurang berarti bagi masyarakatnya, tidak sesuai dengan kebutuhan masyarakatnya. Demikian pula sebaliknya, tanpa peran yang optimal dari pemerintahan Kecamatan, pembangunan akan berjalan secara tidak 
teratur dan tidak terarah, yang akhirnya akan menimbulkan permasalahan baru. Selain memerlukan keterlibatan masyarakat, pembangunan juga membutuhkan strategi yang tepat agar dapat lebih efisien dari segi pembiayaan dan efektif dari segi hasil. Pemilihan strategi pembangunan ini penting karena akan menentukan dimana peran pemerintah dan dimana peran masyarakat, sehingga kedua pihak mampu berperan secara optimal dan sinergis.

Setiap orang yang berada di Negara kesatuan republik Indonesia pastinya sudah tidak asing lagi dengan istilah kelurahan, kelurahan yang dipimpin oleh kepala kelurahan atau lurah yang juga merupakan pegawai negeri yang diangkat oleh bupati atau wali kota atas nama gubernur dengan memperhatikan syarat dan ketentuan yang berlaku sesuai dengan perundang-undangan.

Lurah adalah pemimpin disebuah desa yang posisinya berada dibawah camat. Istilah lurah sering kali racuh dengan sebutan kepala desa (kades). Hal ini karena pada masa jamannya Belanda di Indonesia, istilah desa hanya dipakai di jawa, Madura, dan Bali. Hal ini terjadi karena pada waktu itu yang mengatur desa adalah Belanda. Undang-undang Belanda yang mengatur itu disebut Inlandsche geemente ordonnantie buitengewesten (sbtl.1938 Nomor 490 Jo Sbtl. Nomor 681) sebelum dikeluarkannya undang-undang nomor 5 tahun 1979 tentang pemerintah desa.

Kelurahan yang dipimmpin oleh seorang lurah merupakan termasuk kedalam bagian lembaga eksekutif yang paling rendah. Sebagai seorang pemimpin, lurah memang memiliki banyak peran dalam kepemimpinannya, antara lain sebagai fasilitator, peran sebagai pemecah masalah, sebagai komunitator dan sebagai pengayom bagi masyarakat yang dipimpinnya. Tidak hanya sebatas itu lurah juga mempunyai tugas, fungsi dan wewenang yang telah diatur dalam peraturan pemerintahan, salah satu tugas lurah didalam peraturan pemrintah republik Indonesia pasal 4 ayat (1) yakni lurah sebagaimana dimaksud dalam pasal 3 ayat (2) mempunyai tugas pokok menyelenggarakan urusan pemerintahan, pembangunan dan kemasyarakatan. Memang pada faktanya lurah atau kelurahan adalah lembaga terendah eksekutif namun lurah juga memberi pengaruh dan dampak yang besar terhadap tumbuh kembangnya lembaga eksekutif di Indonesia.

Berdasarkan observasi awal yang dilakukan, adapun permasalahan mengenai Peranan Lurah khususnya dalam mendorong pembangunan di Kecamatan Ujung Tanah dimana kurangnya partisipasi masyarakat dalam pembangunan. Selain itu juga,belum diketahui bagaimana kebijaksanaan Lurah dalam menangani pembangunan di Kecamatan Ujung Tanah Kota Makassar.

\section{METODE}

Dalam penelitian ini penulis menggunakan pendekatan kualitatif. Menurut Bogdan dan Taylor dalam Moleong (2007) menyatakan bahwa penelitian kualitatif adalah sebagai prosedur penelitian yang menghasilkan data deskriptif berupa kata-kata tertulis atau lisan dari orang-orang dan perilaku yang diamati. Penelitian ini dipilih karena untuk menyajikan data secara sistematis, faktual, dan akurat mengenai fakta-fakta yang ada di lapangan. Dengan menggunakan desain penelitian deskriptif dengan pendekatan kualitatif bertujuan untuk menggali mengenai fakta mengenai parsipasi masyarakat kecamatan Ujung Tanah dalam mendukung dan mewujudkan program program pembangunan.

\section{Lokasi Penelitian}

Penelitian ini akan dilakukan di kecamatan Ujung Tanah Kota Makassar. Adapun pelaksaan penelitian pada bulan Maret - April 2020.

Sejak awal memasuki lapangan dan selama proses pengumpulan data, peneliti berusaha untuk menganalisis dan mencari makna dari data yang dikumpulkan yaitu dengan cara mencari pola, tema, hubungan persamaan, hal-hal yang sering timbul dan sebagainya yang dituangkan dalam kesimpulan yang masih bersifat tentative, akan tetapi dengan bertambahnya data melalui proses verifikasi secara terus menerus, maka akan diperoleh kesimpulan yang bersifat "grounded". Dengan kata lain setiap kesimpulan senantiasa terus dilakukan verifikasi salama penelitian berlangsung yang melibatkan interpretasi peneliti.

\section{HASIL DAN PEMBAHASAN}

Peran Aktif, Partisipatif dan Pasif Lurah dalam mendorong Pembangunan di Kecamatan Ujung Tanah

Dalam rangka untuk melihat sejauh mana peran lurah dalam mendorong pembangunan di kecamatan Ujung Tanah Kota Makassar maka ada tiga kelurahn yang dijadikan objek penelitian daam penelitian ini. Kelurahan tersebut adalah kelurahan Tabaringan yang dikepalai oleh Andi Muh. Yusuf, S.STP, kemudian kelurahan Pattingalloang yang dikepalai oleh Drs. Irfan dan kelurahan Gusung yang dikepalai oleh Muh. Ridha, SE.

Ketiga kelurahan ini dijadikan tempat penelitian sekaligus dalam rangka memberikan barometer sejauh mana tindakan yang dilakukan oleh masing-masing lurah sehingga berdampak kepada pembangunan diwilayahnya. Tindakan ini akan dilihat dalam hal peran yang dilakukan apakah dilakukan melalui peran aktif, peran partisipatif dan/atau peran pasif (Soerjono Soekanto).

Kecamatan Ujung Tanah terdiri dari delapan kelurahan yaitu kelurahan Barrang Caddi, Barrang Lompo, Camba Benua, Cambaya, Gusung, Kodingareng, Pattingalloang, dan Pattingalloang Baru. Dari hasil wawancara peneliti dengan camat Ujung Tanah (Bapak Drs. Andi Unru, M.Si) kepada peneliti mengungkapkan bahwa:

"Kegiatan pembanguna yang ada di kecamatan Ujung Tanah semuanya berjalan dengan baik. Dari delapan kelurahan yang ada semua lurah antusias dan seriuas untuk membangun di kecamatan Ujung Tanah. Selama ini tidak yang bermasalah dan 
sesuai dengan yang kita harapkan." (Wawancara 27 Juli 2020)

Dalam rangka percepatan pembangunan di kecamatan Ujung Tanah maka ujung tombak pembangunan ada pada setiap kelurahan. Karna itu peran aktif dari pemerintah kelurahan menjadi kunci utama dalam menyukseskan segala agenda-agenda pemerintahan. Seperti yang diungkapkan oleh sekretaris kecamatan (Bapak Andi Saiful, SE., M.Si) kepada peneliti bahwa:

"Upaya yang dilakukan oleh setiap lurah yang ada di kecamatan Ujung Tanah sebagai ujung tombak pembangunan yang ada di kecamatan kami dilakukan melalui peran aktif dan peran partisipatif. Sejauh ini tidak ada lurah yang pasif dalam bekerja, apalagi hal sesuai dengan perintah dari walikota Makassar agar lurah sebagai ujung tombak pembangunan di kota Makassar bekerja secara proaktif dan terus menunjukkan prestasi." (Wawancara, 27 juli 2020)

a. Kelurahan Tabaringan

Kelurahan Tabaringan adalah kelurahan dengan tingkat pembangunan yang cukup maju yang ada di kecamatan Ujung Tanah. Tentu prestasi ini tidak terlepas dari peran kepala kelurahan dalam mendorong segala upaya dalam menunjang pembangunan didaerahnya. Hal wawancara peneliti dengan lurah Tabaringan (Bapak A. Muh. Yusuf, S.STP) mengungkapkan kepada peneliti bahwa:

"Selama ini yang kita lakukan dalam upaya mendorong pembangunan di kelurahan Tabaringan adalah melalui partisipasi aktif dari setiap jajaran yang ada di kelurahan kita. Jadi kita sudah komitmen bahwa pembangunan di kelurahan Tabaringan adalah tanggungjawab setiap pegawai mulai dari atasan sampai bawahan. Artinya bahwa bukan hanya kepala yang kerja atau sebaliknya pegawai saja yang bekerja, tetapi kita bersamasama." (Wawancara, 28 Juli 2020)

Berkaitan dengan potensi yang dimiliki oleh kelurahan Tabaringan cukup baik mulai dari potensi sumberdaya manusia, tempat pelelangan ikan dan kegiatan industry rumah tangga masyarakat. Berdasarkan hasil wawancara peneliti dengan kepala kelurahan Tabaringan (Bapak A. Muh. Yusuf, S.STP) kepada peneliti mengungkapkan bahwa:

"Di kelurahan Tabaringan kita mempunyai potensi yang cukup baik dalam upaya mendukung pembangunan. Potensi tersebut terlihat dari banyaknya anak-anak muda yang meemiliki kemampuan daya kreatif dan inovatif yang tinggi. Apalagi wilayah kota Makassar terkenal sebagai kota industri dan tempat banyak masyarakat dari berbagai macam daerah mencari lapangan pekerjaan, tentu ini kita harus manfaatkan dengan baik. Karna itu di kelurahan kita kita mendorong industri-industri rumah tangga yang kreatif yang melibatkan anak-anak muda dan ibu-ibu rumah tangga." (Wawancara, 28 Juli 2020)

Sementara itu berkaitan dengan ide dan gagasangagasan kreatif, di kelurahan Tabaringan salah satu ide kreatif yang dibuat oleh lurah Tabaringan dalam upaya mendorong pembangunan yang ada diwilayahnya adalah program "lorong garden". Pada perlombaan lorong garden yang diselenggarakan oleh kecamatan Ujung Tanah, kelurahan Tabaringan terpilih sebagai juaranya dengan penghargaan sebagai kelurahan dengan penataan yang indah, asri dan sejuk. Hasil wawancara peneliti dengan kepala kelurahan Tabaringan (Bapak A. Muh. Yusuf, S.STP) kepada peneliti mengungkapkan bahwa:

"Ada program pemerintah kota Makassar yang diperlombakan di kecamatan Ujung Tanah yang mengikutsertakan semua kelurahan yang ada di kecamatan Ujung Tanah. Program tersebut adalah program lorong garden dimana program ini tujuannya adalah penataan lorong dan rumahrumah penduduk. Dalam perlombaan tersebut kelurahan Tabaringan keluar sebagai juaranya dari semua kelurahan yang ada di kecamatan Ujung Tanah." (Wawancara, 28 Juli 2020)

Ketika peneliti mengonfirmasi strategi yang digunakan dalam mensukseskan program tersebut kepala kelurahan Tabaringan (Bapak A. Muh. Yusuf, S.STP) kepada peneliti mengungkapkan bahwa:

"Pendekatan kepada masyarakat menjadi kunci utama dalam mensukseskan program apapu itu bentuknya. Pendekatan ini dilakukan melalui penampungan aspirasi dan pelibatan mereka secara penuh dalam setiap pelaksanaan program. Dengan cara demikian mereka merasa dihargai sehingga dengan sukarela dan penuh antusias bekerja mensukseskan program tersebut. Pendekatan ini pula berfungsi sebagai sarana pemerintah dalam rangkah memberikan sosialisasi akan manfaat dari program tersebut sehingga mereka dapat mengetahuinya." (Wawancara, 28 Juli 2020)

Namun ada masalah yag cukup esensial berkaitan dengan pembangunan yang ada di kelurahan selama ini. Masalah tersebut adalah masalah sumber pendanaan yang sangat terbatas. Pendanaan selama ini untuk kebutuhan pembangunan fisik misalnya hanya bergantung dari dana pemerintah pusat melalui Dana Alokasi Khsusus (DAK) dan dana dari pemerintah daerah melalui Dana Alokasi Umum (DAU). Itupun pengelolaan penganggarannya tidak menjadi hak sekaligus pemerintah kelurahan.

Hasil wawancara peneliti dengan kepala kelurahan Tabaringan (Bapak A. Muh. Yusuf, S.STP) menungkapkan bahwa:

"Selama ini kita kendala dalam hal pendanaan karna dana yang kita kelolah dikelurahan hanya dana untuk urusan penyelenggaraan pemerintahan. Kegiatan program pmebangunan fisik tidak menjadi tanggungjawab dari pemerintah kecamatan. Jadi yang kita lakukan selama ini jika ada program yang masuk dikelurahan kita sekedar 
membantu untuk mensukseskan karna kuasa pengguna anggarannya bukan ada pada kita." (Wawancara, 28 Juli 2020)

Kelurahan lainnya yang peneliti jadikan sebagai objek penelitian adalah kelurahan Pattingalloang. Kelurahan ini dalam hal pembangunan relative belum maju jika dibandingkan dengan kelurahan Tabaringan. Dalam upaya mendorong pembangunan yang ada di kelurahan Pattingalloang, kepala kelurahan Pattingalloang (Bapak Drs. Irfan) kepada peneliti mengungkapkan bahwa:

"Dalam rangka mendorong pembangunan kelurahan diwilayah kami adalah melalui bantuan dari pemerintah baik itu pusat maupun kota dan juga dari sumbangan masyarakat. Peran sumber pendanaan ini menjadi kunci dalam mewujudkan pembangunan yang ada diwilayah kami." (Wawancara, 29 Juli 2020)

Tabel 1. Jumlah Kepala Keluarga Berdasarkan Jenis Pekerjaan

\begin{tabular}{|c|c|c|c|c|c|c|c|c|c|}
\hline \multirow[b]{2}{*}{ Nama Kelurahan } & \multicolumn{7}{|c|}{ Bekerja } & \multirow[b]{2}{*}{ 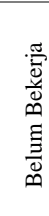 } & \multirow[b]{2}{*}{ Total } \\
\hline & 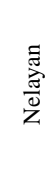 & 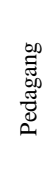 & 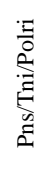 & 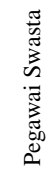 & 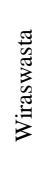 & 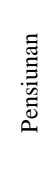 & 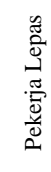 & & \\
\hline 1 Gusung & 5 & 72 & 51 & 147 & 8 & 189 & 92 & 103 & 667 \\
\hline 2 Pattingalloang & 172 & 57 & 62 & 288 & 20 & 234 & 282 & 178 & 1.293 \\
\hline 3 Tabaringan & 28 & 72 & 51 & 147 & 8 & 189 & 92 & 149 & 736 \\
\hline \multicolumn{9}{|c|}{ Jumlah Keseluruhan } & 2.696 \\
\hline
\end{tabular}

Sumber: Kecamatan Ujung Tanah Tahun 2020

Angkatan kerja di kelurahan Pattiangalloang relative lebih banyak dibandingkan dengan kelurahan lainnya di kecamatan Ujung Tanah. Kebanyakan dari masyarakat Pattingalloang berprofesi sebagai nelayan dan juga sebagai pegawai swasta di kota Makassar. Kondisi yang demikian menjadikan banyak anak muda di kelurahan Pattingalloang lebih memilih bekerja di tempat tersebut. Hasil wawancara dengan kepala kelurahan Pattingalloang (Bapak Drs. Irfan) kepada peneliti mengungkapkan bahwa:

"Kebanyakan masyarakat kita berprofesi sebagai nelayan dan pegawai swasta sehingga anak-anak muda di kelurahan kamijuga lebih memilih menjadi buruh-buruh nelayan di pelelangan ikan atau buruh di perusahaan-perusahaan. Mungkin karna orang tua dari dulu kebanyakan berprofesi demikian sehingga turun-temurun itu juga yang kebayakan dilakakun oleh masyarakat kita. Tetapi bukan tidak mungkin ini akan sangat potensial jika anak-anak muda memikirkan ide-ide kreatif dan inovatif dalam rangka mendukung pekerjaan yang berpuluh-puluh tahun digeluti tersebut." (Wawancara, 29 Juli 2020)

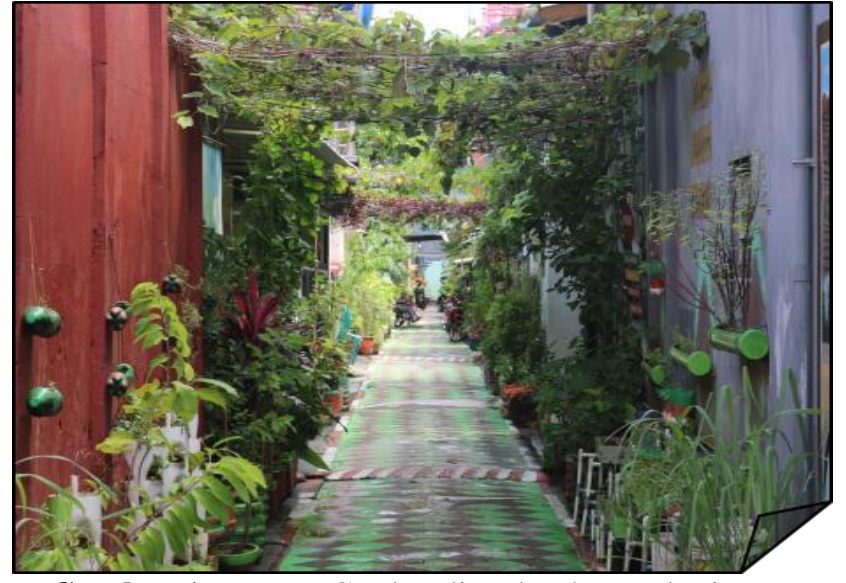

Gambar 1. Lorong Garden di Kelurahan Tabaringan Sumber: Foto Peneliti di Lorong Garden Kelurahan Tabaringan

Sementara itu pada kelurahan Pattingalloang kegiatan kreatif yang juga dilakukan hampir sama dengan yang dilakukan oleh kelurahan Tabaringan. Program tersebut adalah lorong garden, dimana program ini adalah program dari pemerintah kota Makassar yang mensyaratkan kepada semua kelurahan di kota Makassar untuk mewujudkan program tersebut. Hasil wawancara peneliti dengan kepala kelurahan Pattingalloang (Bapak Drs. Irfan) kepada peneliti mengungkapkan bahwa:

"Kita memilki program lorong garden yang merupakan program dari pemerintah kota Makassar. Program ini kita lakukan dalam rangka menara kelurahan kita, seperti mengecet lorong, pembuatan taman-taman dilorong, pembenahan rumah-rumah pendudukan dll. Selama ini kita lakukan sudah cukup baik dan hasilnya juga dapat dilihat secara langsung di masyarakat.” (Wawancara, 29 Juli 2020)

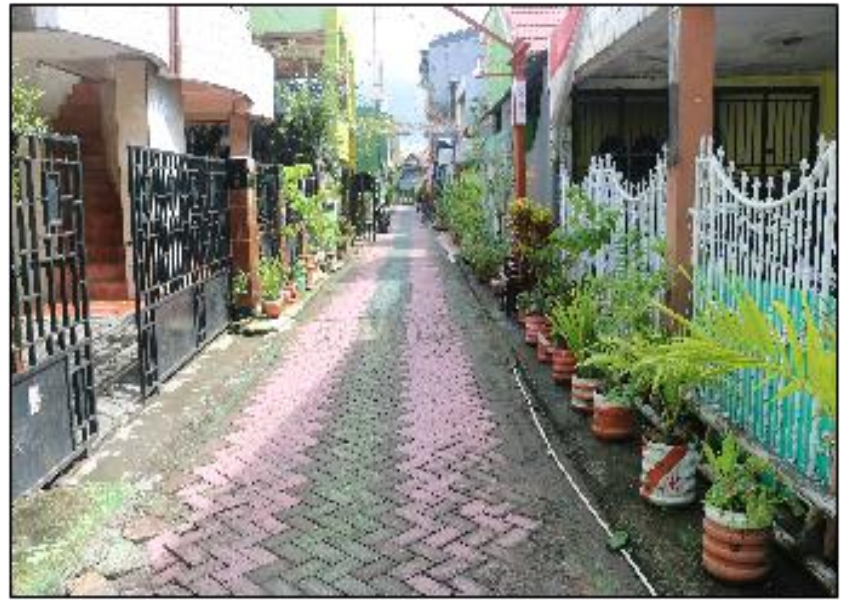

Gambar 2. Lorong Garden di Kelurahan Pattingalloang Sumber: Foto Pribadi Peneliti Tahun 2020

Salah satu persoalan yang cukup krusial di kelurahan Pattingalloang berdasarkan data statistik kota Makassar adalah berkaitan pembangunan manusia yaitu masalah gizi buruk. Tentu masalah ini akan sangat berdampak kepada keberlangsungan generasi masa depan yang akan melanjutkan stafet pembangunan yang ada di kelurahan Pattingalloang. Berikut data keadaan penduduk kelurahan 
Pattingalloang yang peneliti oleh dari data statistik kota Makassar tahun 2019.

Tabel 2. Jumlah Gizi Lebih, Gizi Baik, Gizi Kurang, dan Gizi Buruk

\begin{tabular}{llccll}
\hline No & $\begin{array}{l}\text { Nama } \\
\text { Kelurahan }\end{array}$ & $\begin{array}{l}\text { Gizi } \\
\text { Lebih }\end{array}$ & $\begin{array}{l}\text { Gizi } \\
\text { Baik }\end{array}$ & $\begin{array}{l}\text { Gizi } \\
\text { Kurang }\end{array}$ & $\begin{array}{l}\text { Gizi } \\
\text { Buruk }\end{array}$ \\
\hline 1 & Tabaringan & 7 & 339 & 28 & 5 \\
2 & Pattingalloang & 1 & 356 & 14 & 13 \\
3 & Gusung & 2 & 231 & 11 & 2 \\
\hline
\end{tabular}

Sumber: BPS Kota Makassar Tahun 2020

Dari tiga kelurahan yang dijadikan barometer di kecamatan Ujung Tanah, kelurahan Pattingalloang menjadi kelurahan dengan tingkat gizi buruk yang paling tinggi yaitu berjumlah 13 kasus. Hal ini tentu berhubungan dengan program pembangunan yang dicanangkan oleh pemerintah yang ada di kota Makassar yang diturunkan sampai pada pemerintahan ditingkatan kelurahan. Dari hasil wawancara peneliti dengan kepala kelurahan Pattingalloang (Bapak Drs. Irfan) berkaitan dengan hal tersebut diungkapkan bahwa:

"Persoalan gizi buruk yang terjadi di kelurahan Pattingalloang adalah suatu masalah yang kita alami dan tentu butuh perhatian yang serius atas nama pemerintah dalam hal untuk mengatasi masalah tersebut. Walaupun sebetulnya angka tertinggi gizi buruk di kecamatan Ujung Tanah bukan di kelurahan Pattingalloang melainkan kelurahan Cambaya dengan jumlah sebanyak 12 kasus. Karna itu kita sedang mengupayakan dalam bentuk program yang kita buat dalam rangka untuk mengatasi hal demikian.” (Wawancara, 29 juli 2020)

Sementara itu berkaitan dengan ide dan gagasan dari lurah Pattingalloang sebagai kepalah pemerintahan tertinggi yang ada kelurahan dalam rangka mendorong pembangunan yang ada di wilayahnya, kepala kelurahan Pattingalloang (Bapak Drs. Irfan) kepada peniliti mengungkapkan bahwa:

"Selama ini yang kita lakukan adalah menunggu instruksi dari pemerintah kota melalui pemerintah ditingkat kecamatan. Kita ini bertugas sebagai pelaksana dilapangan yang fokus bekerja untuk masyarakat. Pada saat diperintakan oleh atasan kita mengerjakan sesuai dengan perintah tersebut. Apalagi dalam hal pembuatan program tentu membutuhkan anggaran sementara anggaran dikelurahan ini dalam hal kegiatan pembangunan fisik tidak ada sama sekali yang dikelolah langsung oleh kelurahan. Jadi selama ini menunggu saja dari atasan program-program yang akan dikerjakan di wilayah kami sekaligus tanggungjawab pendanaannya." (Wawancara, 29 Juli 2020)

b. Kelurahan Gusung

Kelurahan Gusung adalah kelurahan lainnya yang ada di kecamatan Ujung Tanah dengan tingkat kemajuan dan pembangunan daerahnya yang relative masih tertinggal dibandingkan dengan sebelas kelurahan lainnya yang ada di kecamatan Ujung Tanah. Sekalipun penduduknya relative lebih sedikit dibandingkan dengan kelurahan lainnya yang ada di kecamatan Ujung Tanah. Berdasarkan data yang diperoleh peniliti dari data yang disuguhkan oleh BPS kota Makasssar tahun 2019 kepadatan penduduk per $\mathrm{Km} 2$ berada pada angka 2.706 lebih tinggi dari penduduk kelurahan Tabaringan dengan kelurahan Pattingalloang yang dari persentase jumlah penduduk jauh lebih besar.

Tabel 3. Jumlah Rumah Tangga, Penduduk dan Kepadatan Penduduk

\begin{tabular}{|c|c|c|c|c|c|}
\hline \multirow[b]{2}{*}{ No } & & & & & \multirow{2}{*}{\begin{tabular}{l}
\multicolumn{2}{l}{ Kepadata } \\
$\mathrm{n}$ \\
$\mathrm{Km}^{2}$
\end{tabular}} \\
\hline & $\begin{array}{l}\text { Nama } \\
\text { Kelurahan }\end{array}$ & Luas $\left(\mathrm{Km}^{2}\right)$ & $\begin{array}{l}\text { Rumah } \\
\text { Tangge }\end{array}$ & Penduduk & \\
\hline 1 & Tabaringan & 0.55 & 1.001 & 4.481 & 1.820 \\
\hline 2 & Pattingalloang & 0.60 & 1.299 & 5.611 & 2.165 \\
\hline 3 & Gusung & 0.18 & 487 & 3.162 & 2.706 \\
\hline
\end{tabular}

Sumber: BPS Kota Makassar tahun 2020

Dalam hal kegiatan pembangunan di kelurahan Gusung dilakukan melalui peran serta dari masyarakat setempat. Peran tersebut ditujukkan melalui pelibatan masyarakat seperti yang diungkapkan oleh kepala kelurahan Gusung (Bapak Muh. Ridha, SE) kepada peneliti bahwa:

"Selama ini yang kita lakukan dalam mendorong pembangunan yang ada di kelurahan Gusung adalah meminta partisipasi RT/RW dalam hal percepatan pembangunan seperti untuk pembangunan fisik kita meminta dukungan baik dalam bentuk tenaga maupun pemikiran untuk bersama-sama memikirkan pembangunan ayang ada di kelurahan Gusung ini." (Wawancara, 29 Juli 2020)

Sementara itu potensi yang dimiliki oleh kelurahan Gusung seperti yang diungkapkan kepala kelurahan Gusung (Bapak Muh. Ridha, SE) kepada peneliti mengungkapkan bahwa:

"Potensi yang dimilki oleh kelurahan Gusung adalah kelurahan Gusung memilki tempat pelelangan ikan Pottere' yang merupakan pusat penjualan ikan nelayan terbesar di Makassar selain itu kelurahan Gusung juga memiliki pelabuhan Pottere'. Dengan adanya tempat pelelangan ikan dan pelabuhan di kelurahan Gusung memudahkan masyarakat sekitar untuk memanfaatkan potensi ini dalam bentuk menambah pendapatan bagi masyarakat sekitar. (Wawancara, 29 Juli 2020)

Sebagai kelurahan yang menjadi pusat penjualan ikan terbesar di kota Makassar idealnya harus juga dibarengi dengan ide-ide keatif dari pemerintah bersama dengan masyarakatnya agar supaya terjadi lonjakan pendapatan dan kemajuan pembangunan wilayah kelurahan Gusung. Jika masyarakatnya sejahterah dan memiliki tingkat pendapatan yang cukup baik maka juga akan secara langsung berdampakan kepada indeks pembangunan yang ada diwilayah tersebut.

Karna itu, berkaitan dengan gagasan atau ide dari lurah dalam rangka mendorong pembangunan yang ada di kelurahan Gusung, kepada peneliti kepala kelurahan Gusung (Bapak Muh. Ridha, SE) mengungkapkan bahwa: 
"Pembangunan yang kita lakukan adalah pembangunan fisik seperti pembuatan reinase pada tahun 2018 yang bekerjasama dengan BKM kota Makassar. Pembangunan sarana fisik ini dilakukan dengan melihat kebutuhan masyarakat. Hal lai yang kita lakukan adalah pemasagan vafing blok di lroong-lorong rumah warga agar jalannya dapat lebih bagus. Intinya kalau ada anggaran pasti akan kita kerjakan sesuai dengan petunjuk dan arahan dari atasan kami." (Wawancara, 29 Juli 2020)

Dalam hal pendanaan mayoritas dari pemerintah kelurahan mengeluh dengan sistem pendanaan pada pemerintah kelurahan. Selama dana yang dikelolah oleh kelurahan hanya sebatas dana oprasioanal untuk mendukung penyelenggaraan pemerintahan. Urusan pendanaan untuk program dalam bentuk fisik tidak dikelolah langsung oeh lurah. Selama ini pembangunan fisik yang masuk pada setiap kelurahan adalah tugas pembantuan yang anggarannya sudah tersedia tinggal dikerjakan oleh pemerintah ditingkat kelurahan tersebut.

Sesuai dengan hasil wawancara peneliti dengan kepala kelurahan Gusung (Bapak Muh. Ridha, SE) mengungkapkan bahwa:

"Pendanaan yang selama ini digunakan dalam membangun khususnya pembangunan dalam bentuk fisik di kelurahan Gusung biasanya berasal dari pemerintah pusat dan/atau pemerintah kota Makassar. Jadi kalau ada program masuk di kelurahan sudah sepaket dengan anggarannya tinggal sampai di kelurahan langsug dikerja. Ini yang kemudian sering menjadi kendala dilapangan bagi kelurahan kami karna kita tidak bisa membuat program untuk masyarakat dalam bentuk fisik karna kita tidak punya anggaran yang cukup." (Wawancara, 29 Juli 2020)

Faktor Pendorong dan Penghambat yang Mempengaruhi Lurah dalam Mendorong Pembangunan

\section{a. Faktor Internal}

Peran masyarakat pada aspek ini, yang pertama yang dilihat adalah seperti apa kesadaran masyarakat itu sendiri dalam mendukung program pembangunan yang ada. Dalam wawancara peneliti dengan kepala kelurahan Tabaringan (Bapak A. Muh. Yusuf, S.STP) kepada peneliti diungkapkan bahwa:

"Kesadaran masyarakat Tabaringan dalam mendukung pembangunan di wilayah kelurahan kami sangat tinggi. Terbukti dengan adanya program-program yang kami buat maupun program yang merupakan instruksi pemerintah dari atas kami selalu mengerjakannya dengan baik dan sudah banyak pula mendapat penghargaan. Sebagai contoh misalnya ketika program lorong garden, kelurahan Tabaringan keluar sebagai pemenang dari delapan kelurahan yang ada di kecamatan Ujung Tanah.” (Wawancara, 28 Juli 2020)

Upaya ini dalam rangka untuk meningkatkan kesadaran masyarakat tentu tidak terlepas dari peran serta daripada lurah itu sendiri. Peran ini ditunjukkan dengan kemampuan kepemimpinan yang dimilki sehingga masyarakat jadi tertarik untuk berpartisipasi. Ketika peneliti melakukan konfirmasi berkaitan dengan strategi yang dilakukan oleh kelurahan Tabaringan sehingga masyarakatnya tingkat kesadarannya sangat tinggi dalam mendukung pembangunan, kepala kelurahan Tabaringan (Bapak A. Muh. Yusuf, S.STP) kepada peneliti mengungkapkan bahwa:

"Yang paling utama adalah membangun pendekatan kepada masyarakat. Karna kalau sudah dekat, kita dengan mudah mensosialisasikan program kita. Sehingga masyarakat jadi tahu apa pentingnya program yang kita sedang rencanakan itu bagi masyarakat sekitar sehingga secara bersama-sama kita harus terlibat mensukseskannya. Selain itu penting juga kita memperlihatkan keterbukaan informasi kepada masyarakat sebagai bagian dari niat tulus kita untuk memperbaiki daerah itu. Hal ini penting karna kalau pemerintahnya tidak terbuka atau tidak transparan maka masyarakat bisa jadi banyak curiga sehingga mereka jadi tidak senang dalam membantu kita. Dan ini modal besar yang selama kita lakukan atas nama lurah Tabaringan." (Wawancara, 28 Juli 2020)

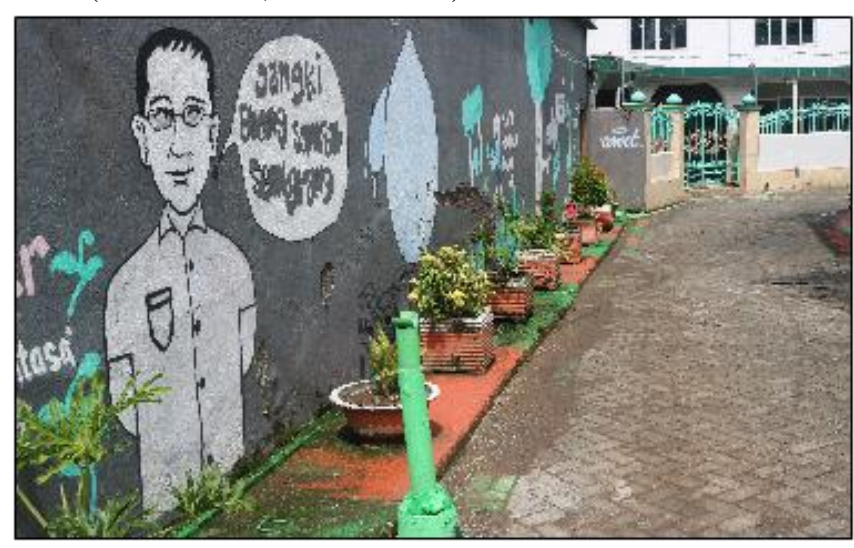

Gambar 3. Lorong Garden di Kelurahan Tabaringan Sumber: Foto Pribadi Peneliti Tahun 2020

Selain modal pendekatan kepada masyarakat, lurah kelurahan Tabaringan juga mendorong pelibatan masyarakat dalam bentuk memberdayakan semua potensi yang ada. Masyarakat dari semua golongan terlibat bukan hanya pada saat bekerja tetapi ketika dalam proses perencanaan ide dan gagasan mereka ditampung sebagai aspirasi. Dalam hasil wawancara peneliti dengan kepala kelurahan Tabaringan (Bapak A. Muh. Yusuf, S.STP) kepada peneliti diungkapkan bahwa:

"Memberdayakan masyarakat setempat itu adalah bagain kunci suksesnya. Karna ketika mereka terlibat sejak dari proses perencanaan maka mereka akan merasa bertanggungjawab untuk mensukseskan program tersebut karna itu adalah ide dari mereka. Dikelurahan Tabaringan kita melakukan pertemuan dengan masyarakat setempat secara formal tiga bulan sekali. Itu berarti didalam setahun rata-rata kita melakukan 
pertemuan dalam bentuk musyawarah sebanyak empat kali setahun. Kalau secara aturan pelaksanaannya sekali setahun yaitu kegiatan musrenbang saja, namun kita tidak lakukan seperti itu mengingat situasi dan kebutuhan pembangunan yang ada di kelurahan Tabaringan." (Wawancara, 28 Juli 2020)

Sementara itu kesadaran masyarakat yang ada di kelurahan Pattingalloang seperti yang diungkapkan oleh kepala kelurahan bahwa masyarakt sangat sadar dalam mendukung pembangunan. Dari hasil wawancara peneliti dengan kepala kelurahan Pattingalloang (Bapak Drs. Irfan) kepada peneliti diungkapkan bahwa:

"Kesadaran masyarakat di kelurahan Pattingalloang dalam mendukung pembangunan sangat tinggi. Jika ada program yang akan dikerjakan semua masyarakat tidak ada yang ketinggalan untuk bersama-sama menyukseskan program tersebut. Tidak ada masyarakat kami yang sekedar melihat jika ada program yang sementara dikerjakan." (Wawancara, 29 Juli 2020)

Ketika peneliti melakukan konfirmasi strategi yang dilakukan sebagai kepala kelurahan dalam rangka untuk meningkatkan kesadaran tersebut, kepala kelurahan Pattingalloang (Bapak Drs. Irfan) kepada peneliti mengungkapkan bahwa:

"Selama ini yang kita lakukan adalah melakukan sosialisasi kepada masyarakat dengan cara melibatkan pegawai yang ada dikelurahan dan juga tokoh masyarakat serta melalui imam-imam mesjid. Mereka dalam setiap pertemuan dengan warga memberikan edukasi kepaad mereka kenapa penting kita terlibat secara langsung dalam setiap program-program pembangunan yang ada didaerah kita." (Wawancara, 29 Juli 2020)

Sementara itu kesadaran masyarakat yang ada di kelurahan Gusung dalam mendorong pembangun seperi yang diungkapkan oleh kepala kelurahan Gusung (Bapak Muh. Ridha, SE) kepada peneliti diungkapkan bahwa:

"Masyarakat Gusung sangat sadar dan antusias dalam mendukung setiap pembangunan yang ada dikelurahan Gusung. Selama ini tidak ada masyarakat yang tidak berpartisipasi secara total dalam setiap rencana pembangunan yang kita buat. Hal inilah yang membuat tidak program pembangunan yang ada dikelurahan gusung tidak kita kerjakan dengan baik." (Wawancara, 29 Juli 2020)

Cara yang dilakukan oleh kepala kelurahan Gusung dalam mengajak masyarakat sehingga sadar untuk terlibat dalam pembangunan dilakukan melalui peran serta lembaga organisasi pemerintahan yang ada di kelurahan Gusung. Hasil wawancara peneliti dengan kepala kelurahan Gusung (Bapak Muh. Ridha, SE) kepada peneliti bahwa:

"Secara kelembagaan kita memiliki perangkat organisasi yang bertugas untuk memberikan sosialisasi kepada masyarakat tentang pembangunan yang ada diwilayah kami. Termasuk peran serta dalam hal ini adalah kepala RT/RW dimasing-masing wilayah yang ada di kelurahan Gusung. Mereka secara proaktif mengajak dan menyadarkan masyarakat apa pentingnya kita harus bersama-sama menyukseskan pembangunan yang ada diwilayah kita." (Wawancara, 29 Juli 2020)

Selain kesadaran masyarakat hal pendukung lainnya dalam membantu pembangunan adalah pendidikan dari masyarakat setempat. Dari tiga kelurahan yang dijadikan objek dalam penelitian di kecamatan Ujung Tanah ini, ada perbedaan tingkat pendidikan masing-masing kelurahan yang cukup signifikan mempengaruhi pembangunan yang selama ini dilakukan. Berikut tabel tingkat pendidikan kecamatan Ujung Tanah di tiga kelurahan.

Tabel 4. Tingkat Pendidikan Masyarakat Kecamatan Ujung Tanah Ditiga Kelurahan

\begin{tabular}{cccccccc}
\hline Nama Kelurahan & $\begin{array}{c}\text { Tidak } \\
\text { Tamat } \\
\text { SD/MI }\end{array}$ & $\begin{array}{c}\text { Tamat } \\
\text { SD/MI }\end{array}$ & $\begin{array}{c}\text { Tamat } \\
\text { SLTP/M } \\
\text { TSN }\end{array}$ & $\begin{array}{c}\text { Tamat } \\
\text { SLTA/ } \\
\text { MA }\end{array}$ & $\begin{array}{c}\text { Tamat } \\
\text { PT/ } \\
\text { Akademi }\end{array}$ & Total \\
\hline 1 & Tabaringan & 44 & 256 & 191 & 534 & 192 & 1.217 \\
\hline 2 & Pattingalloang & 234 & 436 & 218 & 335 & 67 & 1.293 \\
\hline 3 & Gusung & 14 & 241 & 101 & 250 & 61 & 667 \\
\hline \multicolumn{2}{l}{ Sumber: Kecamatan Ujung Tanah Tahun 2020}
\end{tabular}

Dari Tabel 4 tersebut menggambarkan bagaimana tingkat persebaran pendidikan masing-masing wilayah kelurahan berbeda. Angkatan sekolah yang paling banyak adalah kelurahan Pattingaloang yaitu sebanyak 1.293 orang tetapi juga merupakan kelurahan dengan angka pendidikan tidak tamat SD/MI paling tinggi yaitu sebanyak 234 orang.

Sementara itu kelurahan dengan tingkat pendidikan paling tinggi yaitu tamat PT/Akademi adalah kelurahan Tabaringan yaitu sebanyak 192 disusul kelurahan Pattingalloang sebanyak 67 orang dan kelurahan Gusung sebanyak 61 orang. Dari Tabel 4 tersebut terlihat tingkat pendidikan dengan strata tertinggi antara tiga kelurahan yang ada sangat signifikan perbedaan antara kelurahan Tabaringan dengan dua kelurahan lainnya.

Dari hasil wawancara peneliti dengan kepala kelurahan Tabaringan (Bapak A. Muh. Yusuf, S.STP) kepada peneliti mengungkapkan bahwa:

"Dikelurahan Tabaringan ini, banyak masyarakat kita dengan tingkat pendidikan tamat perguruan tinggi atau sarjana. Sehingga ini juga memudahkan kita pemerintah dalam melaksanakan programprogram pembangunan yang ada didaerah kita. Termasuk ketika melibatkan mereka dalam perencanaan pembangunan dimana banyak ide-ide kreatif dan inovatif yang justru berasal dari mereka. Dan inilah salah satu pendukung utama keberhasilan pembangunan di wilayah kelurahan kami." (Wawancara, 28 juli 2020)

Sementara itu ketika peneliti melakukan wawancara dengan kepala kelurahan Pattingalloang (Bapak Drs. Irfan) berkaitan dengan pengaruh tingkat pendidikan 
masyarakat dalam mendukung pembangunan kepada peneliti mengungkapkan bahwa:

"Saya kira berkaiatan dengan tingkat pendidikan masyarakat tidak terlalu mempengaruhi pelaksanaan program kerja pembanguna yang kita sudah buat. Yang paling pening adalah sejauh mana program tersebut tersosialisasi baik kepada masyarakat. Dan itu yang kita lakukan selama ini, dimana masyarakat dari berbagai latar belakang pendidikan tidak jadi soal yang jelas mereka paham dan tahu informasinya berkaitan dengan pekerjaan yang akan dilaksanakan." (Wawancara, 29 Juli 2020)

Senada dengan yang disampaikan oleh kepala kelurahan Gusung (Bapak Muh. Ridha, SE) kepada peneliti bahwa:

"Bagi kami dalam menyukseskan program pembangunan tidak terlalu berdampak tingkat pendidikan masyarakat karna yang kita akan buat perencanaannya sdah dibuat oleh pihak yang terkait. Jadi peran dari masyarakat hanya untuk bekerja saja, tetapi yang terpenting adalah bagaimana informasi pembangunan yang akan kita kerjakan diketahui oleh semua masyarakat." (Wawancara, 29 Juli 2020)

Hal lainnya yang juga berpengaruh dalam upaya mendorong pembangunan yang ada di kecamatan Ujung Tanah di tiga kelurahan yang dijadikan objek dalam penelitian ini yaitu pendapatan masyarakat. Pendapatan masyarakat dipengaruhi oleh tingkat pekerjaan dari masyarakat itu sendiri. Dari tiga kelurahan yang dijadikan objek penelitian, ditemukan bahwa kelurahan Pattingalloang adalah kelurahan dengan jumlah angkatan kerja yang paling banyak dengan persebaran pekerjaan penduduknya dalam berbagai sektor selalu mendominasi (lihat Tabel 4).

Dari hasil wawancara peneliti dengan kepala kelurahan Tabaringan (Bapak A. Muh. Yusuf, S.STP) kepada peneliti diungkapkan bahwa:

"Saya kira pendapatan masyarakat tidak terlalu signifikan dalam mempengaruhi pembangunan yang ada di kelurahan Tabaringan. Jika melihat kepada persepabaran penduduk kami yang bekerja persentasenya lebih kecil dibandingkan dengan kelurahan lainnya yang ada di kecamatan Ujung Tanah. Namun tingkat partisipasi penduduk disini dalam mendukung sangat tinggi”. (Wawancara, 28 Juli 2020)

Sementara itu saat peneliti melakukan wawancara dengan lurah Pattingalloang berkaitan dengan pendapatan masyarakat bahwa mereka cukup berpengaruh karna diakibatkan oleh kebanyakan masyarakat yang ada di kelurahan Pattingalloang berfrofesi sebagai buruh nelayan dengan tingkat pendapatan yang relative kecil sementara waktu mereka bekerja hampir full time. Hasil wawancara tersebut dengan kepala kelurahan Pattingalloang (Bapak Drs. Irfan) kepada peneliti diungkapkan bahwa:

"Kebanyakan masyarakat kita disini berprofesi sebagai nelayan dan kebanyakan diantara mereka adalah buruh di pelelangan ikan. Jadi mungkin karna tidak waktu setelah bekerja sehingga ketika ada pekerjaan yang kita lakukan mereka sangat terbatas keterlibatannya. Sekalipun pada dasarnya mereka sangat mendukung penuh dengan apa yang kita lakukan. Bahkan beberapa diantara mereka yang sangat berterimakasih dengan apa yang kita lakukan." (Wawancara, 29 Juli 2020)

Hal yang sama juga diungkapan oleh kepala kelurahan Gusung (Bapak Muh. Ridha, SE) kepada peneliti bahwa:

"Masyarakat Gusung ini dikenal sebagai kampung para nelayan karna kita banyak masyarakat yang berprofesi sebagai nelayan. Apalagi dikelurahan Gusung ini meruapakan pelelangan ikan doi kota Makassar. Hal ini yang menyebabkan banyak masyarakat kita yang aktifitasnya kebanyakan di pelelangan ikan sehingga waktu untuk kembali kerumah sangat terbatas. Jadi ini sedikit berpengaruh kepada pelaksanaan program kita dilapangan sekalipun mereka kalau ada waktu membantu secara total. Jadi sebenarnya tidak ada masyarakat kita yang tidak mendukung pembangunan yang kita lakukan bahkan mereka sangat mendukung dengan baik dan selama ini banyak mensuport apa yang kita lakukan.” (Wawancara, 29 Juli 2020)

\section{b. Faktor Eksternal}

Berkaitan dengan program pembangunan yang dilakukan oleh pemerintah baik dalam bentuk fisik maupun non fisik cukup mempengaruhi masyarakat dalam pertisipasinya dalam mendukung pembangunan. Darisinilah dibutuhkan ketelatenan lurah disetiap kelurahan dalam rangka memilih dan membuat program sesuai dengan kebutuhan akan kondisi riil di masyarakat.

Hasil wawancara peneliti dengan kepala kelurahan Tabaringan (Bapak A. Muh. Yusuf, S.STP) kepada peneliti mengungkapkan bahwa:

"Jenis program yang kita tawarkan kepada masyarakat memang harus selektif karna jika program tersebut tidak sesuai dengan kondisi riil masyarakat dimana program tersebut akan dikerjakan maka biasanya tidak mendapat respon positif dari masyarakat. Sebagai contoh misalnya ketika program lorong garden dan rumah sampah kita galakkan di kelurahan Tabaringan maka masyarakat dengan sangat antusias untuk terlibat. Ternyata keterlibatan mereka dikarenakan sangat menunjang dalam kehidupan sehari masyarakat setempat. Karna selama ini mereka secara pribadipribadi mengecet lorong mereka atau membuang sampah sembarang tempat. Dengan kedua program ini sangat merubah polah hidup masyarakat kita." (Wawancara, 28 Juli 2020)

Berbeda dengan apa yang disampaikan oleh kepala kelurahan Pattingalloang (Bapak Drs. Irfan), kepada peneliti hubungannya dengan persoalan jenis program yang ditawarkan oleh pemerintah, bahwa:

"Saya kira tidak ada masalah selama ini dengan program apapun yang ditawarkan pemerintah kepada 
masyarakat kami semuanya dikerjakan sesuai dengan program yang ada. Jadi selama ini tidak ada masalah programnya fisik atau nonfisik sama saja yang jelas dapat merubah kehidupan masyarakat dan menunjang pembangunan didaerah itu maka semuanya kita dukung." (Wawancara, 29 Juli 2020)

Hal yang sama juga disampaikan oleh kepala kelurahan Gusung (Bapak Muh. Ridha, SE) kepada peneliti kaitannya dengan jenis program yang selama ini ditawarkan kepada masyarakat, bahwa:

"Sejauh yang kita temui dan alami langsung dilapangan khususnya yang ada dikelurahan Gusung bahwa selama ini program dalam bentuk apapun apakah dia fisik atau non fisik semuanya tidak ada masalah. Masyarakat selalu menerima dengan senang hati ketika ada program yang ditawarkan oleh pemerintah. Apalagi belum ada program kita selama ini yang tidak diterima baik oleh masyarakat." (Wawancara, 29 Juli 2020)

Kaitannya dengan pembangunan yang ada di seluruh kecamatan yang ada di kota Makassar yang kemudian dilaksanakan oleh pemerintah di tingkat kelurahan ada visi dan misi walikota Makassar yang dijadikan acuan. Visi dan misi ini dilakukan secara seragam dan serentak diwilayah kota Makassar. Salah satu visi dan misi kota Makassar adalah "Makassar Tidak Ranatasak". Program ini sangat mengubah prilaku masyarakat kota Makassar yang dulunya tidak peduli dengang kebersihan dan keasrihan lingkungan kini sudah berubah menjadi lebih baik.

Ketika peneliti melakukan wawancara dengan kepala kelurahan Tabaringan (Bapak A. Muh. Yusuf, S.STP) berkaiatan dengan program tersebut dalam wawancaranya kepada peneliti mengungkapkan bahwa:

"Kita menjalankan program walikota Makassar yang salah satunya adalah program Makassat tidak rantasak. Program ini sangat disenangi oleh masyarakat karna dibarengi dengan penataan perkampungan masyarakat sehingga kelihatan lebih sehat, sejuk dan asri." (Wawancara, 28 Juli 2020)

Secara umum pelaksanaan program visi dan misi kota Makassar semuanya diterima baik oleh masyarakat. Hal yang sama juga disampaikan oleh kepala kelurahan Pattingalloang (Bapak Drs. Irfan), kepada peneliti mengungkapkan bahwa:

"Pembangunan yang kita lakukan di kelurahan Pattingalloang berbasis pada semua visi dan misi yang dicanangkan pemerintah kota Makassar. Apapun yang kita kerjakan dikelurahan pijakannya adalah visi dan misi tersebut. Dan ini kita lakukan dengan baik, bahkan sangat didukung oleh masyarakat. Misalnya program Makassar tidak rantasak melalui program lorong garden, dimana program ini sangat bagus dan telah mengubah perkampungan dang pemukiman penduduk menjadi lebih baik." (Wawancara, 29 Juli 2020)

Hal yang sama juga disampaikan oleh kepala kelurahan Gusung (Bapak Muh. Ridha, SE) kepada peneliti soal visi dan misi pemerintah kota Makassar mengungkapakan bahwa:

"Berkaitan dengan visi dan misi walikota Makassar semuanya kita jalankan secara konsekuan sampai di kelurahan Gusung. Jadi apaun kegiatan dalam rangka menunjang visi dan misi tersebut itu dulu yang kita utamakakan. Namun selama initidak ada program kota Makassar yang kita kerjakan dikelurahan tidak disenangi oleh masyarakat." (Wawancara, 29 Juli 2020)

Pemberdayaan masyarakat di kelurahan Tabaringan dijalankan sesuai dengan sebagaimana mestinya. Dimana lurah dalam hal ini membuka ruang seluas-luasnya kepada masyarakat untuk ikut berpartisipasi. Dalam hasil wawancara dengan peneliti kepala kelurahan Tabaringan (Bapak A. Muh. Yusuf, S.STP) kepada peneliti mengungkapkan bahwa:

"Kita membuka ruang seluas-luasnya kepada masyarakat yang ada di kelurahan Tabaringan untuk berpatisipasi dalam pembangunan. Partisipasi mereka ditunjukkan bukan hanya dalam bentuk kita meminta mereka mengerjakan program tetapi mereka terlibat dari awal sejak perencanaan pembangunan tersebut dibuat. Sehingga selama ini banyak ide-ide kreatif dan inovatif yang justru berasal dari masyarakat yang kemudian kita jadikan program pembangunan di kelurahan Tabaringan. Sebagai contoh ketika perlombaan lorong garden, ide penataan lorong sampai kepada arsitektur lorongnya semuanya berasal dari masyarakat." (Wawancara, 28 Juli 2020)

Ketika peneliti melakukan konfirmasi tentang cara yang lurah Tabaringan lakukan sehingga masyarakat ikut berkontribusi melalui perencanaan pembangunan, dalam wawancara yang dilakukan bersama dengan kepala kelurahan Tabaringan (Bapak A. Muh. Yusuf, S.STP) kepada peneliti diungkapkan bahwa:

"Yang paling utama adalah memahami kondisi, kemauan dan harapan dari masyarakat setempat. Itu modal utamanya. Selama yang saya perhatikan di kelurahan Tabaringan ini ada dua kencenderungan masyarakatnya, pertama banyak masyarakat yang memiliki kemampuan diatas rata-rata dalam rangka menjadi patnert diskusi dalam hal ide-ide kreatif. Kedua, banyak anak muda yang sering ingin melampiaskan jiwa seninya tetapi kadang kala tidak mempunyai temapat, ruang dan kesempatan untuk menyalurkan bakat tersebut. Inilah yang kita lakukan yaitu mengajak dan merangkul mereka sesuai dengan kemampuan dan bakatnya." (Wawancara, 28 Juli 2020)

Sementara itu kelurahan Pattingalloang dalam memberdayakan masyarakat sekitar dilakukan melalui strategi dari kepala kelurahan dengan cara membentuk kelompok-kelonpok sosial masyarakat. Misalnya ada kelompok pemuda, kelompok ibu-ibu rumah tangga dll. Hasil wawancara peneliti dengan kepala kelurahan 
Pattingalloang (Bapak Drs. Irfan), kepada peneliti mengungkapkan bahwa:

"Dalam hal pemberdayaan masyarakat di kelurahan Pattingalloang yang kita lakukan adalah membentuk kelompok-kelompok sosial masyarakat. Mulai dari kelompok pemuda dan kelompok ibu-ibu rumah tangga. Mereka inilah yang kemudian terlibat dalam memberikan kontribusi dan pendampingan kepada masyarakat ketika ada program yang akan kita kerjakan". (Wawancara, 29 Juli 2020)

Sementara itu berbeda dengan yang disampaiakan oleh kepala kelurahan Gusung (Bapak Muh. Ridha, SE) kepada peneliti kaitannya dengan strategi yang dilakukan dalam rangka pemberdayaan masyarakat sekitar. Kepada peneliti diungkapkan bahwa:

"Yang kita lakukan selama ini dalam rangka untuk memberdayakan masyarakat yang ada di kelurahan Gusung adalah adalah melalui lembaga PKK yang diinisiasi oleh kaum ibu. Lembaga bertanggungjawab dalam menjaga kesehatan lingkungan serta pendampingan kepada masyarakat jika ada yang bermasalah seperti masalah kekerasan dalam rumah tangga dan lain sebaigainya." (Wawancara, 29 Juli 2020)

Peran Aktif, Partisipatif, dan Pasif Lurah dalam Mendorong Pembangunan di Kecamatan Ujung Tanah

Dalam pandangan Soerjono Soekamto, ada beberapa jenis-jenis peran yang dilakukan oleh seorang pemimpin dalam memajuhkan suatu daerahnya, diantaranya: pertama, eran aktif yaitu suatu peran seseorang seutuhnya selalu aktif dalam tindakannya pada suatu organisasi. Hal tersebut bisa dilihat atau diukur dari kehadirannya serta juga kontribusinya terhadap suatu organisasi. Kedua, peran partisipasif yaitu suatu peran yang dilakukan seseorang dengan berdasarkan kebutuhan atau hanya pada saat tertentu saja. Ketiga, peran pasif yaitu suatu peran yang tidak dilaksanakan oleh individu. Artinya, peran pasif ini hanya dipakai sebagai simbol dalam situasi tertentu di dalam kehidupan masyarakat.

Berdasarkan hasil penelitian peneliti dilapangan dimana pada dasarnya dari tiga kelurahan yang menjadi objek penelitian di kecamatan Ujung Tanah semua tanggungjawab pemerintahan dilakukan melalui perannya sebagai kepala kelurahan dengan baik. Hanya saja ada perbedaan perlakuan yang dilakukan oleh masing-masing lurah dalam melakukan pembangunan didaerahnya.

Konsep pembangunan yang dilakukan oleh pemerintah kelurahan Tabaringan berbasis kepada pendekatan dan pemberdayaan masayarakat. Melalui pendekatan kepada masyarakat antara pemerintah dengan masyarakat lebih terjalin komunikasi yang intens. Kondisi ini membuat jurang pemisah antara pemerintah dan masayarakat sudah tidak ada lagi.

Strategi pendekatan ini cukup berhasil jika dihungkan dengan berbagi macam prestasi yang telah diraih oleh kelurahan Tabaringan selama ini. Masyarakat yang ada di kelurahan Tabaringan bersama-sama dengan pemerintah sehingga setiap ada program yang akan dikerjakan semuanya berjalans sesuai dengan yang sudah direncanakan. Salah satu program yang telah sukses dikerjakan oleh pemerintah kelurahan Tabaringan bersama dengan masyarakat adalah ketika pada tahun 2018 kelurahan Tabaringan keluar sebagai juara pertama perlombaan lorong garden.

Sementara itu berkaitan dengan pemberdayaan masyarakat, kepala kelurahan Tabaringan menggunakan konsep partisipatif dimana masyarakat dilibatkan sejak dari perencanaan sampai kepada tahap implementasi. Program yang dijalankan di kelurahan banyak berasal dari ide dan gagasan dari masyarakat setempat yang kemudian diadopsi oleh pemerintah kelurahan Tabaringan.

Upaya ini sangat optimal karna ternyata dengan cara seperti itu masyarakat merasa dilibatkan secara langsung sehingga menumbuhkan rasa tanggungajawab yang tinggi dalam memajuhkan pembangunan di daerah tersebut. Sehingga tidak sedikit keberhasilan pembangunan yang dicapai oleh kelurahan Tabaringan tidak terlepas dari peran serta masyarakat setempat secara proaktif.

Sementara ada perbedaan perlakuan yang dilakukan oleh kepala kelurahan Pattingalloang dalam hal mendorong pembangunan di wilayahnya. Strategi tersebut ditunjukkan dengan konsep kelembagaan dan ketokohan. Beberapa program yang dibuat oleh pemerintah dijalankan melalui peran dari lembaga-lembaga tersebut termasuk dengan peran tokoh agama seperti untuk mensosialisasikan dan mengajak masyarakat untuk mendukung pembangunan.

Pendekatan kelembagaan dalam hal menggambarkan bahwa peran dari kepala kelurahan dalam menjalakan kepemimpinannya lebih bersifat top down atau dari atas kebawa. Pendekatan ketokohan adalah merupakan startegi utama yang dilakukan oleh kepala kelurahan Pattingalloang. Artinya bahwa peran-peran sosialisasi dan komunikasi menjaditanggungjawab lembaga dan tokohtokoh tersebut.

Hampir sama dengan yang dilakukan oleh lurah Pattingalloang, kepala kelurahan Gusung juga meggunakan metode demikian. Hanya saja pendekatannya murni dilakukan oleh lembaga pemerintahan yang sudah dibentuk didalam stuktur pemerintahan di kelurahan. Pendekatan fungsi dan tugas menjadi cirri utama kepemimpinan yang dilakukan oleh lurah Gusung.

\section{Faktor Pendorong dan Penghambat Lurah dalam Mendoorng Pembangunan}

Hakekat dari suatu pembangunan adalah perubahan secara terus-menerus yang merupakan kemajuan dan perbaikan menuju kearah tujuan yang dinginkan. Proses dimulainya pembangunan dengan berpijak pada pembangunan masyarakat, diharapkan akan dapat memacu partisipasi masyarakat dalam proses pembangunan itu sendiri.

Ginanjar Kartasasmita secara sederhana mengartikan pembangunan sebagai suatu proses perubahan ke arah yang lebih baik melalui upaya yang dilakukan secara terencana. Semenatara itu Sondang P Siagian (2001) 
mendefenisikan pembangunan sebagai suatu usaha atau rangkaian usaha pertumbuhan dan perubahan yang terencana yang dilakukan secara sadar oleh suatu bangsa, negara dan pemerintah, menuju modernitas dalam rangka pembinaan bangsa.

Konsepsi pembangunan dibagi dua kategori diantaranya, pembangunan fisik dan pembangunan non fisik di dalam kehidupan masyarakat. Fisik dalam istilah pembangunan meliputi sarana dan juga prasarana pemerintahan seperti: a) Jalan; b) Jembatan; c) Pasar; d) Pertanian; dan e) Irigrasi.

Didalam pembangunan suatu wilayah bukan hanya melakukan program pembangunan yang bergerak dibidang pembanguan fisik saja tetapi juga harus bergerak dibidang pembangunan non fisik atau sosial. Bachtiar Effendi (2002:114) oleh karena itu, pembangunan hendaknya harus adanya keseimbangan antara pembangunan fisik ataupun pembangunan non fisiknya. Yang menjadi bagian dari pembangunan non fisik atau sosial yaitu: a) Pembangunan manusia; b) Ekonomi; c) Kesehatan; dan d) Pendidikan.

Dalam hasil penelitian yang telah ditemukan peneliti dilapangan bahwa peran yang dijalankan oleh masingmasing kelurahan yang dijadikan objek dalam penelitian ini juga memperlihatkan cara yang berbeda. Didalam penentuan program pembangunan yang ada dikelurahan Tabaringan dilakukan secara selektif. Dalam pernyataan yang disampaikan oleh lurah Tabringan bahwa program yang tidak relevan dengan kondisi masyarakat kelurahanTabaringan biasanya tidak mendapat respon yang positif dari masyarakat setempat.

Konsep partisipatif menjadi kunci pamungkas pemerintah kelurahan Tabaringan. Karna itu setiap program yang dihasilkan sudah dipastikan sesuai dengan kebutuhan dan keinginan masyarakat yang ada di kelurahan Tabaringan. Hal ini dikarenakan dalam proses perencanaan pembangunan masyarakat sudah terlibat secara penuh bahkan diakui dalam satu tahun saja ratarata empat kali pemerintah kelurahan Tabaringan melakukan musyawarah atau diskusi secara formal.

Sementara berbed dengan kelurahan Pattingalloang dan kelurahan Gusung dimana berdasarkan pernyataan dari kepala kelurahan baik iru kelurahan Pattingalloang dan kepala kelurahan Gusung menyampaikan bahwa program yang diturunkan kepada msyarakat selama initidak ada masalah. Jenis program apapun yang diberikan kepada masyarakat mereka dengan senang hati dan tidak ada masalah dalam pengimplementasiannya. Bahkan justru mereka banyka bersyukur dan mensuport ketika ada program yang masuk terlepas program tersebut bentuknya fisik atau non fisik.

\section{KESIMPULAN DAN SARAN}

Kesimpulan hasil penelitian ini bahwa peran lurah dalam mendorong pembangunan yang ada di kecamatan Ujung Tanah dilakukan melalui peran aktif dan peran partisipatif. Faktor penghambat dalam upaya mendorong pembangunan di kecamatan Ujung Tanah kesadaran masyarakat, tingkat pendidikan, dan pendapatan dari masyarakat. Dalam rangka mendorong pembangunan yang lebih baik di masa yang akan dating sebaiknya peran lurah dalam menjalankan programnya dilakukan secara partsispatif dimana masyarakat dilibatkan secara langsung. Sebaiknya program yang dibuat oleh pemerintah baik dalam bentuk fisik atau non fisik dibuat berdasrkan kebutuhan riil yang di wilayahnya.

\section{DAFTAR PUSTAKA}

Chester L. Hunt dan Paul B. Horton, 1993. Sosiologi, Jakarta: Penerbit Erlangga.

Effendi, Bachtiar. 2002. Pembangunan Daerah Otonomi Berkeadilan. Yogyakarta: Uhaindo dan Offset.

Linton, Ralph. 1968. The Study of Man : an Introduction. Applenton Century. New York.

Riyadi. 2002. Perencanaan Pembangunan Daerah Strategi Mengendalikan Potensi Dalam Mewujudkan Otonomi Daerah. Jakarta. Gramedia.

Selo Soemardjan dan Soelaeman Soemardi. 1974. Setangkai Bunga Sosiologi. Jakarta: Yayasan Badan Penerbit Fakultas Ekonomi Universitas Indonesia.

Soerjono Soekanto, 2009. Peranan Sosiologi Suatu Pengantar, EdisiBaru, Rajawali Pers, Jakarta.

Sondang P. Siagian. 2001. Manajemen Sumber Daya Manusia. Jakarta: Bumi Aksara.

Thoha, Miftah. 2002. Perilaku Organisasi Konsep Dasar dan Aplikasinya. Jakarta: Rajawali Grafindo Persada.

Undang-Undang nomor 5 tahun 1979 tentang Pemerintah Desa. 